\title{
Inequality and Poverty Alleviation: Globalization, Access, and Gender
}

\author{
Ade Marsinta Arsani \\ Directorate of Expenditure Account \\ BPS-Statistics Indonesia \\ Jakarta, Indonesia \\ ademarsinta@gmail.com
}

\begin{abstract}
The high economic growth in Indonesia has not been followed by economic equality. The economic inequality is usually in line with poverty. In developing countries, economic inequality and poverty are not only the economic problems but also social problems. Globalization, the lack of access to public facilities, democracy issues, gender equality and unemployment may affect the decrease of poverty and economics inequality. This study is aimed to determine the dominant roles in reducing the inequality and poverty in Indonesia. This study applied 20112015 data from Statistics Indonesia and Bappenas. Globalization was proxied by trade globalization, democracy was represented by Indonesia Democracy Index, and unequal access to public and social facilities was represented by regions (western Indonesia and eastern Indonesia) and women HDI. Meanwhile, unemployment was proxied by unemployment index, and gender equality was represented by Gender Development Index. Multiple regression analysis and two stages least square regression analysis were applied in this study. Multiple regression analysis was used to analyze the effects of independent variables to economics inequality and poverty separately. Meanwhile, two stages least square regression analysis was used to analyze the effects of independent variables to economics inequality and poverty simultaneously. The result shows that economics inequality was affected by poverty, but not vice versa. Based on that, a policy on reducing poverty should be prioritized. Poverty can be reduced by improving access to public and social facilities (especially for women), opening up to globalization and creating labor-intensive jobs to reduce unemployment. When poverty has declined, access to public and social facilities in Eastern Indonesia should be improved to optimize the inequalityreducing policy. In addition, a policy in reducing gender inequality should also be effectuated. This study is expected to be taken into consideration in the preparation of priority programs in order to reduce economic inequality and poverty alleviation.
\end{abstract}

Keywords - economics inequality; poverty; globalization; gender

\section{INTRODUCTION}

In 2016, Indonesia's economic growth reached 5.02 percent. Indonesia's economic growth is one of the highest among G20 member countries. However, this growth was not followed by the decline of domestic economic inequality. The wealth gap between the rich and the poor is still quite wide. This can be seen from the value of Gini ratio which reached 0.397 in March 2016. Another fact, the result from the survey of Swiss financial institutions, Credit Suisse, showed that almost half of Indonesia's national wealth was controlled by only 1 percent of richest people. This condition was only better than Russia, India, and Thailand (Katadata, 2017). It made the Indonesian economic inequality rank the sixth worst position in the world. Inequality income distribution would lead to disparity between regions. (Musfidar, 2012). Poverty cannot be separated from economic inequality. The determinants of inequality also affect poverty, directly and indirectly. Although the movement of poverty is not always in line with economic inequality, poverty has always been one of the main reasons for inequality.

Technological change, global trade, changes in the structure of employment, economic growth, and education are considered to be major factors leading to widening income inequality. This is also reinforced in Halmos (2011) which stated that exports affected the inequality of income distribution. Besides its effect on inequality, globalization also has a strong influence on poverty. According to Kuznets (1955) there was a positive correlation between economic growth and the inequality of income distribution; the higher the economic growth, also reflected by per capita income, the greater the difference between the poor and the rich, especially in the early stages of development. Then, Mbaku (1997) did a research about the relationship between economic development indicators and economic inequality and found that there was strong relationship between HDI and economic inequality. Social inequality is also expected to influence the change in economic inequality and poverty. Here, social inequality is proxied by the value of gender inequality. Poverty and economic inequality are also inseparable from political policy. Directly or indirectly, political policies taken by the government might affect the welfare of the population. Although there is no definitive theory about the relationship of political policy to economic inequality and poverty; some studies show that political quality, in this case, democracy plays a role in reducing economic inequality and poverty. Political policies that will be realized in the form of government programs are expected to embrace all parties. Currently, in Indonesia there is still a dichotomy between Western Indonesia and Eastern Indonesia. Eastern Indonesia is stigmatized more retarded than in Western Indonesia. The access difficulty to this region makes the prices higher than 
other parts of Indonesia. This is also the cause of high poverty rates, especially in the Maluku and Papua.

\section{LITERATURES REVIEW}

In this era, poverty and inequality become two main problems in developing countries. On his article, Poverty and Inequality, Beteille (2003) argued that there are unclear relationship between poverty and inequality. Analytically, poverty and inequality have different concept. It is misleading to assume that the existence of one of them is a sign of the existence of another. Usually, an interest in economic and social problems has been associated with poverty and inequality.

The discussion about the relationship between poverty, inequality and economic growth is characterized by uncertainty in the relationship between all of them. Several researches conducted in different regions and times showed different relationships between poverty, inequality and economic growth. Angelsen \& Wunder (2006) concluded two important things: First, economic growth and income redistribution could be used as primary instruments on poverty alleviation policies; Second, economic growth would lead to poverty reducing process. But when it was accompanied by bad income distribution, it would increase poverty.

One of the driving forces of the economy is labor. The lack of labor and manpower will create unemployment and will contribute to inequality. González\&Menendez (2000) and Whiteford\&Van Seventer (2000) found that increase in income inequality can be explained by the increase in unemployment. By theories, distribution of assets and income are influenced by many factors, such as unemployment, education, government policies, etc. Due to the political system, government policy has a close relationship with the market system. Many researches such as Acemoglu and Robinson (2000), showed negative relationships between inequality and democracy using cross-country studies. On the other hand, Sirowy and Inkeles (1990) and Gradstein and Milanovic (2004), argued that the relationship between democracy and inequality is not robust and ambiguous. The democracy affects not only inequality, but also poverty. Political elites commitment in alleviating poverty can force bureaucratic institutions to turn the commitment into public policy. Varshney (1999) argued that land reform and tenancy reform can reduce the dependence of the poor on landlords. This condition would create a more stable income condition.

Not only the economic and political factors, but social inequality also contributes to the economic inequality and poverty. USAID (2015) stated that although the causal relationship between social inequality and poverty was unclear, most countries with high gender inequality had higher poverty rate than countries having more gender equality rate. A new analysis showed that social inequality, especially gender inequality, significantly affects hunger and poverty. Evidence shows that zero hunger and poverty are not able to achieve until gender equality is reached (Bread for The World, 2016).

\section{DATA AND METHODOLOGY}

This research uses the 2011-2015 data from Statistics Indonesia and Ministry of National Development Planning (Bappenas). The study overviews a mapping of economic inequality and poverty in Indonesia as well as describes factors affecting both variables.

Table 1. Variables' Definition and The Formula

\begin{tabular}{|c|c|c|}
\hline Variables & Definition & Formula \\
\hline Gini Ratio & $\begin{array}{c}\text { Measure of income distribution } \\
\text { calculated based on income } \\
\text { class. }\end{array}$ & $G R=1-\sum_{i=1}^{n} f_{p i}\left(F c_{i}+F c_{i-1}\right)$ \\
\hline Economic Growth & $\begin{array}{l}\text { An increase in market value } \\
\text { adjusted for inflation of goods } \\
\text { and services produced by an } \\
\text { economy over time. }\end{array}$ & $\frac{\text { GRDPconst }_{t}-\text { GRDPConst }_{t-1}}{\text { GRDPconst }_{t-1}} \times 100 \%$ \\
\hline Poverty Rate & $\begin{array}{l}\text { the percentage of the population } \\
\text { below the poverty line }\end{array}$ & $P_{0}=\frac{1}{n} \sum_{i=1}^{q}\left[\frac{z-y_{i}}{z}\right]$ \\
\hline $\begin{array}{l}\text { Female Human } \\
\text { Development } \\
\text { Index }\end{array}$ & $\begin{array}{l}\text { Female HDI indicates how the } \\
\text { female population can access } \\
\text { development results in obtaining } \\
\text { income, health, education, and } \\
\text { so on. }\end{array}$ & 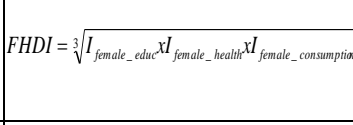 \\
\hline $\begin{array}{l}\text { Gender } \\
\text { Development } \\
\text { Index }\end{array}$ & $\begin{array}{l}\text { An indicator to measuring the } \\
\text { achievement of HDI's } \\
\text { dimensions, and reveals the } \\
\text { injustice of achievement of male } \\
\text { and female. }\end{array}$ & $G D I=\frac{\text { FemaleHDI }}{\text { MaleHDI }} \times 100 \%$ \\
\hline Unemployment & $\begin{array}{l}\text { The percentage of } \\
\text { unemployment to the total labor } \\
\text { force. }\end{array}$ & Directly from BPS \\
\hline $\begin{array}{c}\text { Trade } \\
\text { Globalization }\end{array}$ & $\begin{array}{l}\text { the ratio between the volume of } \\
\text { foreign trade with gross } \\
\text { domestic product }\end{array}$ & $T G=\frac{\text { ForeignExport }+ \text { Foreignimport }}{\text { GRDP }} \times 100 \%$ \\
\hline $\begin{array}{c}\text { Indonesia } \\
\text { Democracy Index }\end{array}$ & $\begin{array}{l}\text { is an objective and empirical } \\
\text { measurement tool for the } \\
\text { condition of provincial political } \\
\text { democracy in Indonesia }\end{array}$ & Directly from BPS \\
\hline Region & $\begin{array}{l}\text { Classification of Indonesia's } \\
\text { territory }\end{array}$ & $\begin{array}{c}0=\text { Eastern Indonesia, } 1 \text { = Western } \\
\text { Indonesia }\end{array}$ \\
\hline
\end{tabular}

The study applied the simultaneous model analysis using SUR (Seemingly Unrelated Regression), to determine factors affecting the economic inequality and poverty simultaneously; since it is said that economic inequality and poverty theoretically have a close relationship.

The models are written as follow:

$$
\begin{aligned}
& G R=\beta_{0}+\beta_{1} G G R D P_{i t}+\beta_{2} \text { Poverty }_{i t}+\beta_{3} G D I_{i t} \\
& +\beta_{4} \text { Unemploy }_{i t}+\beta_{5} I D I_{i t}+\beta_{6} T G_{i t}+\beta_{7} \operatorname{Re} \text { gion }_{i t}+\varepsilon_{i t} \\
& \text { Poverty }=\beta_{0}+\beta_{1} G G R D P_{i t}+\beta_{2} G R_{i t}+\beta_{3} F H D I_{i t} \\
& +\beta_{4} \text { Unemploy }_{i t}+\beta_{5} I D I_{i t}+\beta_{6} T G_{i t}+\varepsilon_{i t}
\end{aligned}
$$


Where:

\section{GR: Gini Ratio}

GGRDP: economics growth (\%)

Poverty: poverty rate $(\%)$

GDI: Gender Development Index

FHDI: Female Human Development Index

Unemploy: Unemployment rate (\%)

IDI: Indonesia Democracy Index

TG: Trade Globalization

Region: Dummy variable for western and eastern Indonesia

$\varepsilon:$ error term

i: province $\mathrm{i}$

$\mathrm{t}$ : time

\section{RESULT AND DISCUSSION}

The initial test results show that there is a correlation between the residuals produced by Equation (1) and (2). Therefore, the modeling of these equations used the SUR model. Statistically, the equation formed is as follows:

Table 2. Seemingly Unrelated Regression Result

\begin{tabular}{|c|c|c|}
\hline \multirow[b]{2}{*}{ VARIABLES } & \multicolumn{2}{|c|}{ SUR Model } \\
\hline & GR & Poverty \\
\hline GGRDP & $\begin{array}{c}0.420 * * * \\
(0.110)\end{array}$ & $\begin{array}{c}-0.497 * * * \\
(0.131)\end{array}$ \\
\hline Poverty & $\begin{array}{c}0.428 * * * \\
(0.0504)\end{array}$ & \\
\hline GDI & $\begin{array}{c}0.0732 \\
(0.0893)\end{array}$ & \\
\hline Unemploy & $\begin{array}{l}0.212 * \\
(0.121)\end{array}$ & \\
\hline IDI & $\begin{array}{l}0.164 * * * \\
(0.0433)\end{array}$ & $\begin{array}{c}-0.182 * * * \\
(0.0553)\end{array}$ \\
\hline TG & $\begin{array}{c}0.0288 * * * \\
(0.00877)\end{array}$ & $\begin{array}{c}-0.0537 * * * * \\
(0.00998)\end{array}$ \\
\hline Region & $\begin{array}{r}-0.0150 \\
(0.574)\end{array}$ & \\
\hline GR & & $\begin{array}{c}0.832 * * * \\
(0.0862)\end{array}$ \\
\hline FHDI & & $\begin{array}{c}-0.491 * * * \\
(0.0728)\end{array}$ \\
\hline Constant & $\begin{array}{c}10.60 \\
(7.838)\end{array}$ & $\begin{array}{c}28.89 * * * \\
(5.329)\end{array}$ \\
\hline Observations & 165 & 165 \\
\hline R-squared & 0.136 & 0.512 \\
\hline
\end{tabular}

Standard errors in parentheses

$* * * \mathrm{p}<0.01, * * \mathrm{p}<0.05, * \mathrm{p}<0.1$

Source: Data processing

\section{A. Inequality and Poverty}

Gini ratio is a measure of income distribution calculated based on income class. Practically, the calculation of Gini ratio in Indonesia used the expenditure approach. During the period 2011-2015, the average Gini ratio in 33 provinces in Indonesia was 0.38 . This figure showed that inequality in 33 provinces was quite moderate. The lowest Gini ratio of 0.28 was found in the provinces of Bangka Belitung and North Maluku in 2015 while the highest gini ratio was in Gorontalo province in 2011.

Similar to the Gini ratios, in Indonesia, poverty rate also used an expenditure approach. The poverty rate in 33 provinces in Indonesia in the period of 2011-2015 was relatively moderate in the average range of 12.25 percent. The highest poverty rate was 31.98 percent in Papua in 2011 while the lowest poverty was in DKI Jakarta in 2015 at 3.61 percent.

Beteille (2003) said that there is no definite theory of the relationship between poverty and inequality. In many cases, poverty and inequality have the same direction, but in other cases they have opposite directions. In Indonesia, poverty and inequality showed a positive and mutually influencing relationship. High-poverty areas tended to have high inequality. Likewise, economic inequality would also affect poverty. Naschold (2002) said that income distribution affected poverty significantly; then Wodon (1999) said that the impact of change on income distribution was not only in poverty rate but also on the depth and severity of poverty.

\section{B. Economic Growth}

The average of annual regional economic growth in Indonesia during 2011-2015 was 4.12 percent. Provinces that rely on mineral mining as the main export commodity tended to experience fluctuating growth during this period. This was due to the volatility of the world mineral mining price and the existence of export restriction policy for mineral ores.

The highest annual economic growth occurred in 2015 in West Nusa Tenggara province by 19.69 percent. This high growth occurred because in 2015 , Nusa Tenggara returned to export iron ore after experiencing export restrictions in the previous year. Meanwhile, the lowest economic growth of 6.19 percent was experienced by Papua in 2011.

Economic growth is closely linked to poverty and inequality. Although Kuznet's theory was denied in many countries, but for the case of provinces in Indonesia in the period of 2011-2015, this theory was still valid. In contrary, in this study, economic growth affected poverty negatively. The higher the economic growth, the lower the poverty. This shows that the economic growth has included inclusive economic growth. The result of the study conducted by BPS in 2013 showed that the quality of Indonesia's economic growth has been satisfactory but quite partially, and constantly increasing every year (Badan Pusat Statistik, 2013).

\section{Gender Development Index}

This indicator is an approach of social inequality that is expected to affect economic inequality. In this study gender inequality is reflected by the gender development index. During the study period, the average of gender development index in 33 provinces was 89.32. The results of this study indicate that during the study period, social inequality, in this 
case gender inequality had no effect on the economic inequality. This might be because the level of gender equality in Indonesia was good enough. There was no significant discrepancy between men and women. Meanwhile, the economic inequality in Indonesia was still quite high.

\section{Female Human Development Index}

This index is a representation of how women can access development's result. In general, within the study period, the score of Female HDI was 64.08. This score was relatively lower than the score of Male HDI in the same period. This Female HDI score was classified as medium.

One of the critical factors in the poverty alleviation is the empowerment of women. The result of The United Nations Fourth World Conference on Women (1995) point 49 said that not only contributed to the economy, women also contributed in combating poverty. The results of this study also show a similar thing. Female HDI's scores are negatively related to poverty. The higher scores of Female HDI, the smaller percentage of poor people in a region. Thus, improving women's ability to access building results can serve as a breakthrough for poverty alleviation.

\section{E. Unemployment Rate}

This indicator reflects the percentage of the labor force that is not absorbed in the production process. During the study period in 33 provinces in Indonesia, the average of the unemployment rate was 5.74 percent. Unemployment is closely related to inequality, especially inequality regarding income distribution. This study shows that unemployment rate is positively correlated with the Gini ratio. The higher the unemployment rate then the inequality will increase. This is in line with many international research reviews, including the research conducted by González and Menendez (2000). Their research found that the increase in unemployment could explain almost $50 \%$ of the change on income inequality

\section{F. Indonesia Democracy Index}

This indicator reflects the democratic and political conditions in a region. Because politics and security are two inseparable things, this indicator also serves as a proxy for security conditions in a region. The higher the index score, the better the political and democratic conditions in that region. During the study period, the mean score of IDI in 33 provinces in Indonesia was 67.52. This score is classified as moderate. Democracy, which is closely related to policy, is expected to affect the inequality. The results of this study indicate that democracy will increase inequality. This result is an early indication that the benefits of democracy are not shared evenly by the entire population. Stigler (1970) said that democracy transferred the political power to middle class only and sometimes in nonagricultural societies; inequality increased following a democratization (Acemoglu, et.al, 2013).

\section{G. Trade Globalization}

This indicator shows the interactions between provinces and foreign countries through a trade process. One indicator of the openness of a region is the volume of goods that are in and out into provinces; and, to and from abroad. The average of ratio total volume of foreign trade (exports and imports) to GRDP is 37.38 percent.

International trade transaction is expected to bring not only the goods but also the transfer of science and technology to improve the welfare of all levels of society. The results of this study indicate that globalization triggered the increase of inequality. This result is in line with the description of Era Dabla-Norris (2015) and Halmos (2011) which stated that the global trade is one of the causes of widening economic inequality. This result is an indication that the effects of global trade are still enjoyed by a small portion of the population. The existing international trade has not been able to be a way of disseminating technology that is expected to improve the welfare of the whole society. On the other hand, based on the results of this study, globalization also plays a role in reducing poverty. The higher ratio of total trade volume to GRDP tends to decrease the poverty rate. This result is in line with the studies conducted in several other developing countries.

\section{H. Differences of the West and East}

There is a stigma that inequality in Eastern Indonesia is worse than in Western Indonesia. However, the results of this study do not show that. The model in this study shows that the region has no significant effect on inequality. This means that there is no difference in inequality between Western Indonesia and Easter Indonesia. It is acknowledged that this classification is weak. When the dichotomy of Western Indonesia and Eastern Indonesia was used in this model, the inequality would be seen in the group itself. In fact, there may be differences in living standards between one region and another. This refers to how the calculation of the Gini ratio is used. The calculation of the Gini ratio only considers the distribution of income (which in this case is approximated by expenditure) in the territory itself, not using universal benchmarks. Using the same standard may produce different results.

\section{CONCLUSIONS}

The discussion above shows that the factors affecting inequality and poverty are mutually exclusive. Thus, a simultaneous program is needed to solve both problems. Acceleration of quality economic growth that can absorb labor becomes one of the alternatives. Increasing employment is not enough, but also replenishing the welfare of workers. This will create an equal distribution of income and reduce poverty. In addition to job creation, environments that support women to access development's result are also important. The role of women in reducing poverty is already proven in many countries. Therefore, the education, health, and welfare of women need to be considered to be equal to men. 
In the wider scope, awareness of democracy needs to be improved so that democracy can be beneficial to all levels of society. So far, democracy and the results are only enjoyed by a handful of the population, so it does not look useful, even detrimental, to the decrease in inequality and poverty.

Globalization, in this case, international trade, does affect poverty, but it also increases inequality. To prevent this adverse effect, a policy is needed so that globalization is not only related to economic exchange but also the exchange of science and technology. Economic exchange (trade) will only be benefited by few people. However, science and technology will spread and be applied faster, so it will be beneficial to all levels of society. Thus, inequality will decline.

From the above explanation, it can be concluded that:

1. Factors affecting inequality and poverty are mutually exclusive.

2. Economic growth, poverty, unemployment, democracy and globalization affect the degree of inequality.

3. Inequality, economic growth, women's capacity, democracy, and globalization affect poverty.

4. There is a need for appropriate policies on the economic growth, declining unemployment, and gender equality; so that it can be optimally beneficial in reducing the levels of inequality and poverty alleviation.

5. A policy is needed to minimize the adverse effects of democracy and globalization.

\section{REFERENCES}

[1] Acemoglu, D., \& Robinson, J. A. (2000). Why Did the West Extend the Franchise? Quarterly Journal of Economics, 1167-1199.

[2] Acemoglu, D., Naidu, S., Restrepo, P., \& Robinson, J. A. (2013). Democracy, Redistribution and Inequality. In A. Atkinson, \& F. Bourguignon., Handbook of Income Distribution. Retrieved from https://scholar.harvard.edu/files/.../democracy-and-inequality-december5-2013.pdf

[3] Angelsen, A., \& Wunder, S. (2006). Poverty And Inequality: Economic Growth Is Better Than Its Reputation. In D. Banik, Poverty, Politics and Development: Interdisciplinary Perspectives. Bergen: Fagbokforlaget.

[4] Badan Pusat Statistik. (2013). Analisis Statistik Lintas Sektor: Analisis Pertumbuhan Inklusif 2013. Jakarta: Badan Pusat Statistik.

[5] Beteille, A. (2003, October 18-24). Poverty and Inequality. 38 No 42, 4455-4463. Economic and Political Weekly. Retrieved from http://www.jstor.org/stable/4414161
[6] Bread for The World. (2016, March 16). Bread for The World. Retrieved from Bread for The World: http://www.bread.org/news/genderinequality-worsens-hunger-and-poverty

[7] Era Dabla-Norris, K. K. (2015). Causes and Consequences of Income Inequality: A Global Perspective. Washington: International Monetary Fund.

[8] González, M., \& Menendez, A. (2000). The Effect of Unemployment on Labor Earnings Inequality: Argentina in the Nineties. Working Paper No. 216. Princeton University Woodrow Wilson School of Public. Retrieved from https://www.princeton.edu/rpds/papers/pdfs/menendez_unemployment_ ar.pdf

[9] Gradstein, M., \& Milanovic, B. (2004). A Survey of the Empirical Evidence on the Links between Political Democracy and Income Inequality. Journal of Economic Surveys, 515-537.

[10] Halmos, e. a. (2011). The Effect of FDI, Exports and GDP on Income Inequality in 15 Eastern European Countries. Acta Polytechnica Hungarica Vol. 8, No. 1.

[11] Katadata. (2017, Februari 23). Katadata. Retrieved from Katadata.com: http://databoks.katadata.co.id/datapublish/2017/01/10/di-indonesia-1orang-terkaya-menguasai-49-kekayaan-nasional

[12] Kuznets, S. (1955). Economic Growth and Income Inequality. The American Economics Review.

[13] Mbaku, J. M. (1997). Inequality in Income Distribution and Economic Development: Evidence Using Alternative Measures of Development. Journal Of Economic Development, Volume 22, Number 2, , 57-67.

[14] Musfidar, M. (2012). Faktor-Faktor yang Mempengaruhi Ketimpangan Distribusi Pendapatan Di Sulawesi Selatan Tahun 2001-2010. Makasar: Universitas Hasanudin.

[15] Naschold, F. (2002, March). Why Inequality Matters for Poverty. Inequality Briefing Paper No 2 . London, United Kingdom: Overseas Development Institute.

[16] Sirowy, L., \& Inkeles, A. (1990). The Effects of Democracy on Economic Growth and Inequality: A Review. Studies in Comparative International Development, 126-157.

[17] Stigler, G. J. (1970). Director's Law of public income redistribution. Journal of Law, 1-10.

[18] United Nation. (1995). UN Women: Beijing and it's follow up. Retrieved from UN Women: http://www.un.org/womenwatch/daw/beijing/platform/poverty.htm

[19] USAID. (2015, September). Gender and extreme poverty: Getting to Zero. A USAID discussion series. Retrieved from https://www.usaid.gov/sites/default/files/documents/1870/Gender_Extre me_Poverty_Discussion_Paper.pdf

[20] Varshney, A. (1999). Democracy And Poverty 2000. Conference on World Development Report. Sussex: U.K. Department for International Development.

[21] Whiteford, A., \& Seventer, D. v. (2000). South Africa's changing income distribution in. Studies in Economics and Econometrics, 7-30.

[22] Wodon, Q. (1999). Growth, Poverty and Inequality: A Regional Panel for. Washington D.C: World Bank 